278 KINDER ON RAILWAYS AND COLLIERIES OF N. CHINA. [Selected

\title{
(Paper No. 2474.)
}

\section{"Railways and Collieries of North China." \\ By Cuaude William Kinder, M. Inst. C.E.}

T'He most recent information communicated to the Institution on the subject of Chinese railways is contained in an abstract from a paper by Adolphe Schwarz, published in the "Wochenschrift des oesterreichischen Ingenieur- und Architekten-Vereines." 1 This account contains many errors, and is calculated to give so erroneous a view of the state of affairs, that the Author has felt impelled to write the true history of the matter.

The first systematic attempt to introduce railways into China was made in 1863, and Sir R. Macdonald Stephenson devoted considerable time to the subject at the instigation of various important firms in Shanghai and Hong Kong. A company was proposed with a view to building a line from Shanghai to Soochow, but the project fell through owing to the opposition of the Chinese officials. He then suggested that lines should be built entirely from materials manufactured in China, thus necessitating a minimum of foreign capital and interference, and it is interesting to note that the same idea has now been adopted by the Government after a lapse of twenty-seven years.

As a proof of the meagre knowledge of Chinese ideas prevailing at that time among Europeans, it may be mentioned that a scheme for a line connecting Peking to Calcutta was actually introduced to the astonished Mandarins, who then, as now, consider that any communication whatever with India would be absolutely fatal to China's welfare. It was not until 1876 that the Woosung ${ }^{2}$ line was built, and although it was closed and torn up in October, 1877, it had done good work in demonstrating to thousands of Chinese the advantages of improved communication. The gauge of this railway was only 2 feet 6 inches, and everything

' Minutes of Proceedings Inst. C.F., vol. xcviii. p. 452.

2 See the History of the Shanghai and Woosung Railway, by G. J. Morrison, in the library of the Institution (in MS.); also Rapier on the Woosung Railway, Minutes of Proceedings Inst. C.E., vol. lix. p. 274. 
was on a small scale, owing to want of funds; but it was capable of doing solid work under the management of Mr. G. J. Morrison, M. Inst. C.E. In after years "the remains" became a serious source of trouble, as the authorities showed a desire to make use of the old engines and rolling-stock for the Kaiping line, which, if persisted in, would have caused the introduction of a gauge which the promoters of the Woosung line never intended to propose as suitable for the permanent railways of China.

While H.E. the Viceroy of Nankin was pulling up the Woosung line, the far more powerful and sensible Viceroy of the Northern Provinces, H.E. Li Hung Chang, was settling with the manager of the China Merchants Steam Navigation Company, Mr. Tong King Sing, the preliminaries for opening out a colliery for a supply of coals to the rapidly increasing fleet, to be followed by ironworks, and perhaps a railway, if it should be possible to introduce this objectionable item into the scheme.

The locality for the operations was left until a suitable expert could be obtained from Europe. On the arrival of Mr. R. R. Burnett, M. Inst. C.E., followed by Mr. J. M. Molesworth, M. Inst. M.E., with diamond rock-boring plant, several districts were examined, and in the autumn of 1878 a hole was put down at Tongsan (Fig. 1) some 80 miles N.E. from Tientsin. Coal of excellent quality was proved to exist there, and large quantities of inferior fuel, suitable for native use, were also met with. The best spot for a colliery was found to be at Linsi, $15 \frac{1}{2}$ miles further east; but as this could not be worked without a railway of considerable length, it was necessary to commence operations on an inferior site nearer the market, and it was not until 1888 that shaft-sinking was begun at Linsi, and the line to that point decided on.

The nearest navigable river to Tongsan is the Peh Tang Ho, and it was arranged to build 29 miles of railway to Lutai, an important town on the east bank. The Author then (in 1878) joined the service as Resident Engineer, to survey and construct the line; but, before any effective start could be made, orders came to stop all work, the Imperial sanction for a railway having been withdrawn. After much discussion, it was decided, naturally against the wishes of the engineers, that a canal of 21 miles should be made to connect Lutai with a point some 7 miles $\mathrm{S}$.W. of the colliery site, which latter distance could be covered with a light tramway, worked by mules, as on no account would locomotives be allowed. Fully appreciating the importance of getting any line at all, the energetic director pushed on, attacked on all sides by 


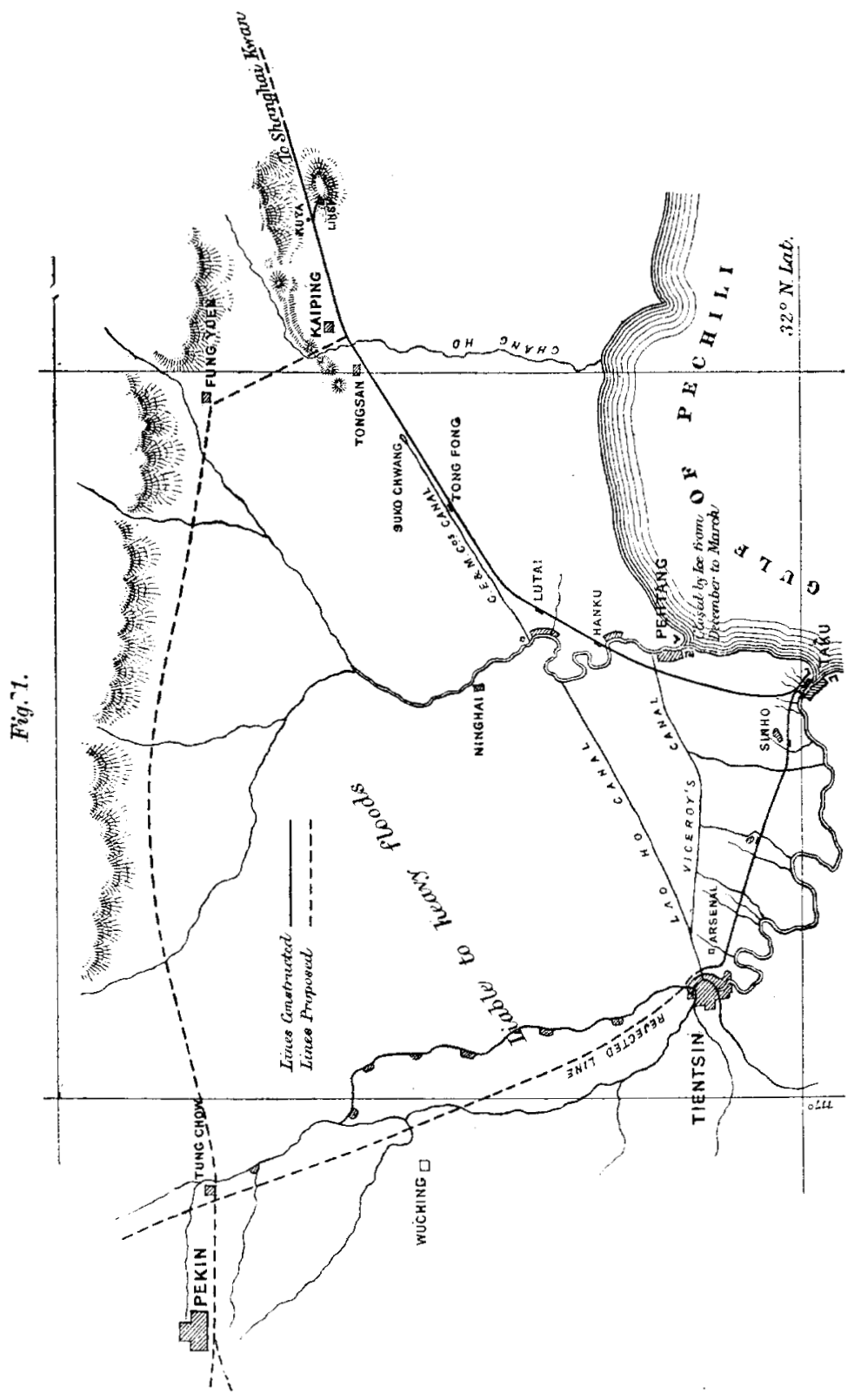


infuriated censors, superstitious natives, and too often deserted by his friends and well-wishers.

To give an idea of the annoyances practised, the following may prove interesting. While surveying, a pole was planted on the summit of a hill where the remains of a rude fortification still exist; this was reported to the throne, and several official despatches were required before the authorities were satisfied that no serious rebellion was contemplated, or the Tongsan Earthdragon likely to be disturbed. Again, when it was proposed, some years later, to use certain iron ores to the N.E., the whole scheme was stopped as being detrimental to the manes of the imperial dead situated about 120 miles in a totally different direction, and so great was the uproar, that the colliery itself, then in full operation, was very nearly closed. The mere sight of a few boring-rods, steam-pipes, or anything with a hole in it, drove the natives frantic with fear of rebels, and for years after they persisted in the belief that, when the time was ripe, the makebelief gas- and water-pipes would become cannon or other terrible weapons of warfare. Pamphlets were circulated accusing the engineers of attempts to unearth the treasure guarded by the dragon, and calling for the immediate destruction of the works. Strikes were common, and caused much delay, to obviate which men from other provinces were imported; but, with the exception of those from Shantung and Canton, few have remained. In spite of the constant assertion that labour was abundant, it was often impossible to secure sufficient hands, especially in the summer months when they were most needed.

The heavy machinery was conveyed to the colliery, partly by carts from Lutai, but chiefly by boats ascending the Chang Ho from the coast, a route involving many tedious transhipments amidst the deep mud and constant rain. This duty was admirably performed by Mr. Molesworth, who had to put up with exposure and hardships rarely met with, even in China. The shafts sunk were both 14 feet in diameter, lined with solid limestone blocks set in cement. No. 1 was carried to a depth of 600 feet; No. 2, serving as an upcast, to a depth of 300 feet only.

Details with respect to the blasting operations have been already communicated by the Author to the Institution. ${ }^{1}$

${ }^{1}$ Minutes of Proceedings Inst. C.E., vol. Ixxx. p 188. 


\section{Coal-Deposits.}

The coal-bearing stratum is here some 800 feet thick, and dips at an angle of from 45 to 60 degrees. It contains thirteen seams, nine of which are worked, having a total thickness of 125 feet; only two are of good quality, viz., No. 2, which is 30 inches thick, and No. 5, 70 inches thick. The latter contains 4.54 per cent. ash, and only 0.97 sulphur.

\section{WORKINGIS.}

On account of the high dip, the workings are laid out on the French and Belgian system.

The coal is cut overhand, the miners standing on "packing" sent down to fill the gob. The rubbish and stone for this purpose is lowered from the surface by self-acting inclines. Where the seams are from 12 to 30 feet or more in thickness, special systems are in use, the coal in such cases being extremely soft, and liable to run. In thin seams of hard coal, props are set as in long wall mining, and afterwards withdrawn, allowing the roof to come down.

The packing system for high dips is certainly the safest, and as it requires little or no timber, it in many cases proves most economical. The great demand for good coal caused the opening out of dip workings in No. 5 seam to a depth of 950 feet, the water and coal being drawn by three powerful engines placed below ground, worked with steam from the surface. The Company, however, propose to use electric-motor pumps and hauling machinery driven by a dynamo on the surface.

The pumping-plant consists of two of Davey's differential engines placed on the surface, with cylinders 50 inches and 30 inches, and a stroke of 6 feet. One of these works two 20-inch lifting-sets in No. 1 shaft, and the other two 20-inch plunger-pumps in No. 2 shaft.

The Guibal fan is 30 feet in diameter by 10 feet wide, and is placed near to the up-cast shaft; at 40 revolutions per minute it passes 120,000 cubic feet of air. It is driven by a high-pressure compound engine, but has an auxiliary single-cylinder engine placed so as to be readily coupled if needed. Walker's shutter has put a complete stop to vibration, which at one time was excessive. The water-gauge is usually as low as 0.60 inch, owing to the large airways and numerous splits. 


\section{Ottput.}

Owing to the closing of navigation during the winter, there is only a small demand for best coals at that season, but inferior coals are always saleable. The output since the commencement has been as follows:-

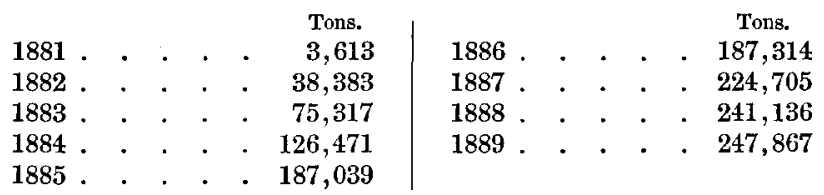

The average cost of production at the mine is nearly 5s. per ton, and the selling prices average as follows :-

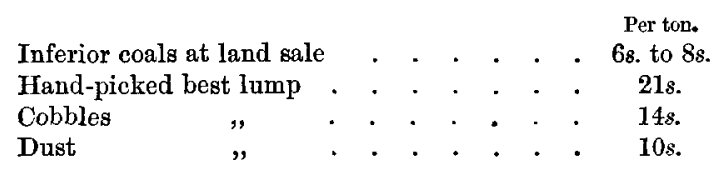

The railway rates for coal-as indeed for everything else-are extremely low, viz., for 7 miles haul, $5 d$. per ton; for 55 miles haul, 2s. 6d. per ton; for 81 miles haul, 2s. 11d. per ton; the rolling-stock being entirely the property of the railway company.

\section{Brick-Works AND PotTeries.}

The beds of fire-clay found in the district are of excellent quality, the best being equal to Stourbridge. The natives have several large potteries besides those belonging to the company, which, however, by the use of steam-power and superiority of site, can manufacture at lower rates. The crushing is done by a Clayton edge-runner mill and a pair of rolls, driven by a portable engine with a cylinder 12 inches by 20 inches. The bricks are rough-moulded by hand, and then pressed by portable machines. Compressed red bricks are made in sheet-iron hand-moulds, and cost 13s. per mil, the pressed fire-bricks costing nearly double this amount, but being of superior quality. A Chinese brick-moulder rarely turns out over four hundred bricks a day, but as his pay is only from $5 d$. to $6 d$. the cost is not excessive, although higher than in many parts of Europe.

The pottery and tiles are all of coarse types, only adapted for native use, large pots being in great demand, and forming 
an important part of the furniture of every house; they are usually about 24 inches in diameter and 40 inches high, glazed inside and out, and are sold at the works for $3 s$. to $4 s$. each.

\section{GAS-WORKS AND LightiNG.}

The works and a large portion of the streets are illuminated by gas made by the Company from No. 5 seam coal, which alone is suitable for the purpose; about six hundred and fifty lights are now in use, and this is still the only part of China where gas is thus employed, except in foreign settlements. ${ }^{1}$

For underground illumination the Company purchase pea-nuts, from which an excellent oil is pressed by the native system of wedges. This oil is afterwards treated either with ammonia or sulphuric acid to render it pure enough for the Marsaut safetylamps.

It has been found that the natives, by their slow "jerking" system of extracting oil, get better results than can be obtained by machinery, but it would not be difficult to improve on their methods if the demand were sufficient to make it worth while.

\section{WORKSHOPS.}

Owing to the isolated position of the colliery, it was necessary to have extensive shops for repairs and for the manufacture of rough mining-plant, which the high dip workings require in great quantity. In addition to this, there was the construction and repair of steam-tugs, barges, locomotives, and wagons for the canal and railway departments. To meet even the present requirements, the shops are already being enlarged.

\section{Geveral.}

A hospital under the charge of an English surgeon, with accommodation for some forty native patients, was at one time very successful, and was crowded with applicants, but a Cantonese establishment, where the knife was never used, and people permitted to die in preference to undergoing a slight operation, gradually won the day, and at present the surgeon only attends Europeans in the service.

1 The Inspector-General of Customs has a private gas-works for his house in Peking. 
A mining college was also started by H.E. Li Hung Chang, but was soon closed, as the authorities failed to remit the taxes which were to have been applied to its support.

The high freights ruling from Europe have rendered the manufacture of Portland cement possible in China, and an establishment for an output of 200 tons per week is now in course of erection. It will be made from mountain limestone and a peculiarly rich clay procured from Canton, and brought up in junks, which return south laden with coal; no suitable clay having been found hitherto in North China.

The Company owns one collier, built in Shanghaj, but three others are now being constructed in England, and the produce of the so-called Kaiping district become daily of more importance. Unfortunately the iron-ore of the locality, although in immense deposits, is so rich in silica that economical smelting is a difficult matter. This may be got over by cargoes of ore from along the coast being sent in return for coals, but as yet no supplies are obtainable. The mineral riches of China have been much exaggerated. Excellent samples of various valuable ores are easily obtained, but, so far, few have been discovered in quantities which have any commercial importance. Shansi has always been held up as containing excellent minerals in immense quantities, but its distance from the centres of trade and from the coast will hamper its development.

\section{LABOUR AND WAGES.}

The average pay of miners employed on day-work is about $7 d$., but many who work on the "butty" system earn twice this amount. The Cantonese are usually employed as petty officials and skilled workmen, and receive from $£ 3$ to $£ 10$ per month in the latter capacity. Unskilled labour is cheaper than in Europe, whilst skilled labour is usually dearer, so that it is better to purchase highly-finished plant exclusively abroad, making the rougher descriptions in China. Payments are made in native bank-notes of small value, in copper cash, in sycee, or in Mexican dollars, the last being the most popular, while the two former are more common. One thousand cash weighs $8 \mathrm{lbs}$., and has a value of $40 \mathrm{~d}$. The sycee is simply a lump of silver fashioned somewhat like a native shoe; it is cut up and weighed as needed, but the "touch" is so variable that only experts can hope to deal in it with safety. A few solid native banks exist, but the majority are risky, and the notes as a rule 
are only available over a limited district. The want of a proper currency is seriously felt, but the officials interested in innumerable exchange shops are very unwilling to permit any improvement. Recently a mint has been opened in Canton, which turns out a Muntz-metal coin worth nominally $55 d$. per mil, but actually costing more than this to manufacture and circulate, so that it is not probable that the issue will be long permitted. By decreasing the size of the coins, and doing away with the square hole in the centre, so dear to the pocketless Chinaman, it would be possible to make them without a loss, but it would be better to have no minted money under 5 cash in value.

\section{The Company's Canat System and Tramway.}

The canal to Lutai with its connecting railway to the colliery were laid out in 1880 and completed in 1881. The water for the former was secured by placing substantial tide-gates, at Lutai and the junction with the Pehtang River, which could be opened on the average for about two hours at each tide. These gates, and eight bridges, were the only works of importance. The minimum depth of water was 4 feet, with a width of 24 feet, the average cutting being 10 feet in depth with slopes $2 \frac{1}{2}$ to 1 . It was, however, found impossible to maintain this depth without constant dredging; the canal, in fact, becoming a mere drain for several hundred square miles of country, previously a swamp for six months in the year. The Company had no power to prevent the natives cutting the banks whenever they pleased, and the canal soon became almost worthless for transport purposes. As it was impossible to secure sufficient boats to convey a large output, the Company built one hundred barges of European type, carrying 25 tons with a draught of 2 feet 6 inches, having angle-iron frames and 2-inch planking; they were towed by tug-boats of various sizes, adapted to the canal or river sections of the route followed, as Chinese prejudices would not permit of mule haulage, which in shallow water is far superior.

The losses by robbery were extensive, being often as high as 15 per cent. of the cargo, and the coal was so injured by the use of water as a make-weight that many steamers refused to accept it, preferring to purchase Japanese coal in Shanghai.

In the meantime the tramway was doing excellent service, and giving a practical illustration of its superiority. In spite of what has often been said to the contrary, from an engineering point of 
view, the canal system of China is exceedingly defective, and it will not be difficult to build railways which can compete with water-transit. The first difficulty met with in the construction of the, tramway was the problem of the gauge to be adopted. Fortunately the correct gauge of 4 feet $8 \frac{1}{2}$ inches was at last sanctioned, thus, it is to be hoped, settling once for all this question for China.

In granting permission for the line it was expressly stipulated that no locomotives were to be used, but even before the track was completed this had virtually become a dead letter. The country was extremely easy, the total rise being only 75 feet, and thanks to some sharp curves, few graves needed removal; subsequently, on the owners objecting to the noise and whistling so near to the bones of their ancestors, the sacred remains were removed and the line straightened up. Considerable difficulty arose in securing land, the people considering it would bring bad luck to sell, and to this moment some of it is retained by the owners, who cultivate the soil right up to the toe of the ballast, and will not permit any side drains to be cut. The track consisted of 30-1b. steel rails laid on half-round native elm sleepers, the ballast being broken limestone from the adjacent quarries. During the winter of $1880-81$ a locomotive of very extraordinary design was quietly built in the shops from various odds and ends procurable without attracting much attention. The boiler belonged to a portable winding-engine, the wheels had been purchased as scrap castings, and the frames were made of channel-iron. Before this engine was finished its preparation became known and strict orders were issued that it should be stopped at once. After a few weeks, during which time H.E. Li Hung Chang was constantly consulted, the monster was allowed to be completed. On the 9 th of June, the first spike was driven by Mrs. R. R. Burnett (the wife of the Engineer-in-chief), and the engine was also christened by her, the Rocket of China, just one hundred years after the birth of George Stephenson. This locomotive was then put into daily use for conveying materials for the tramway, and on the 8th of November took a large party of officials to the canal basin, returning at a speed of over 20 miles per hour; the trip was a great success, nothing more was said about mules, and the stables built for their use were quickly demolished. In October 1882 two tank-engines were purchased from Messrs. Stephenson of Newcastle; these were furnished with cylinders $10 \frac{1}{2}$ inches by 18 inches, with six 42 -inch coupled wheels, and the Rocket was then consigned to shunting work and light ballast-trains.

There is little doubt that if this engine had not been built in 
China by native workmen in Chinese shops, it would never have been allowed to run, and many years would have elapsed before the advantages of steam-traction would have been proved to the quthorities. For some years no more railway work was undertaken, but the Franco-Chinese wars and the threatened stoppage of the tribute-rice steamers aroused the attention of the government, and numerous lines were proposed, examined, and rejected for one reason or another. Her Majesty the Empress became the most prominent advocate of Western improvements, but was firmly opposed by the majority of the Imperial family and various Boards. Schemes of all kinds, more especially for railway concessions, were tried for by European syndicates, but in vain. The French alone met with a slight success, securing the completion of the docks at Port Arthur, ousting the German engineers, who had previously had charge of the work. These docks have recently been completed by Messrs. Thevenet and Griffon, and but for their isolation and purely military character, their construction would never have been allowed to be placed in the hands of foreign contractors.

The tramway at Tongsan had been kept so quiet that although it had been in use for five years, very few high officials had dared to visit it or extol its merits. The government, after being petitioned by His Excellency the Viceroy, permitted the mining company to push its line to |Lutai, for the purpose of conveying coal more readily to the shipping; junks and even steamers of 1,000 tons capacity being able to ascend the river to that point, there was apparently no sufficient reason for extending the tramway any further.

As the mining company had no funds available, a new company called the Kaiping Railway Company, was formed under Chou Fu Taotai of Tientsin, which purchased the old line. Considerable doubt was felt as to its paying merits, and the small sum of $£ 70,000$ was only procured with great difficulty, and no little official pressure, none feeling sure that the scheme could be carried out, or that the Throne would not once more withdraw its sanction. The management was entrusted to Mr. Wu Ting Fang, Interpreter and Secretary to the Viceroy, a gentleman who had been many years in London and had been called to the English Bar. As the capital was limited (only $£ 36,000$ being left after the purchase of the old line and the rolling stock), it was decided to use a 45-lb. steel Sandberg rail, with angle-plate joints, and sleepers of Japanese Hinoki Wood. The canal bank was made use of for most of the distance, and required very little raising to make it suitable for the purpose. The 30 -lb. rail had proved to be quite sufficient 
for a load of 4 tons per wheel at low speeds, but the small platejoints were troublesome; it was therefore concluded that with a rail 50 per cent. heavier and well fished, a good track could be secured well suited to a moderate traffic at low speeds.

For the first time in China, tenders were called for in the orthodox manner, so as to take advantage of the competition for the honour of providing China with what were erroneously supposed to be her "first rails." Messrs. Krupp of Essen, had no difficulty in securing the order, as their offer was considerably below market value, to which their French and English rivals adhered too closely. Nine small bridges were needed, and where the floods swept across the line the track was sunk for a distance of 2,000 feet, so that on such rare occasions the metals would be some 20 inches below water for a short period. Since 1886 no such floods have occurred, and there has been no trouble from this sonrce. The first spike of this extension was driven at Suko Chwang on the 22nd November, 1886, and the line was completed in the following May. The total cost of the new portion, including one American locomotive and forty 10-ton coal wagons, was rather less than $£ 34,000$. The work was carried out entirely by Chinese, the Author being ably assisted by Mr. Kwang King Yang, who had been a student in the United States, and Mr. Hong, a native of Ningpo.

This experiment being successful, the Viceroy immediately pressed for an extension to Pehtang and Taku, chiefly for military purposes, together with a line from there to Tientsin; this latter project had been under discussion for many years, opinions favouring a line on the south bank of the Pei Ho, which, although some 6 miles longer, had the advantage of coming close to the back of the Foreign Settlement. The Author was a second.time invited to report on the subject, and further examination confirmed his opinion that the route on the northern bank of the river should be adopted, as it would permit uninterrupted communication between Tientsin and all points of importance along the north-east coast line, without bridging the Pei Ho, until after passing Tientsin, on the way to Peking. The extension to Tongku was permitted, and the company was rechristened the China Railway Company, the administration, however, remaining in the same hands. Fortunately the Author was able to procure the assistance of Mr. Cox, of Adelaide, and immediately telegraphed for other engineers. The work commenced as soon as the centre line was located; but scarcely was a fair start made than orders were received to at once extend the line to Tientsin, the whole 50 miles

[THE INST. C.E. VOL. CIII.] 
of railroad to be completed in fourteen months. This latter section was to hug the northern bank of the Pei Ho, and it was not until the natives made a great clamour against it, that the direct and correct route was permitted.

\section{Earthworks.}

The Chinese are excellent at all kinds of earthworks, provided sufficient care is taken to keep them in proper line and level, of which little details they are apt to be somewhat careless. The centre line was marked with pegs, 100 feet apart, duly numbered in English and Chinese, but the European figures excited official wrath, and were removed, and what was worse, in many cases the pegs themselves were taken away. In the most difficult places soldiers were employed, and their work was excellent, as they are accustomed to the construction of the mud forts so generally used in China. With few exceptions the earthwork was done entirely from side cuts, which owing to the liability of severe floods could not safely be made deeper than 2 or 3 feet. The only economical way of guarding against the destruction of the embankment was to make it of unusual strength, and where possible to encourage the growth of such plants as could live in the salt-impregnated soil. Fortunately there have been no really bad inundations in this part of the province since 1886, so that the work has had time to become consolidated. It is, however, certain that a flood like that of 1886 , if accompanied by strong winds to cause waves to wash against the slopes, would damage if not destroy the railway for the greater part of its length; but the Author did not consider it justifiable to increase the financial burden of a decidedly poor paying line, by being too unwilling to accept risks which would not be likely to involve danger to life. The average height of bank is 8 feet, with a top width of 27 feet, and slopes nominally $1 \frac{1}{2}$ to 1 ; but in reality much flatter from settlement. The cost varied greatly; in wet places where the men were in mud up to their knees, as in the neighbourhood of Pehtang, as much as $5 \frac{1}{2} d$. per cubic yard was paid, the minimum being about $2 d$. The earth was carried up by one man with two baskets or by two men with one large basket, the cost depending largely on the class of labour employed, i.e., soldiers, canal diggers; or mere villagers and loafers. The best coolies usually do as much as 6 cubic yards a day on short leads, taking it in turns to dig and carry. A square piece of strong cotton cloth is often used instead of a basket, and in certain soils a coarse net of thin ropes. The spades used are short with cross handles, the blades being long and sharp like a 
Papers.] KINDER ON RAILWAYS AND COLLIERIES OF N. CHINA. 291

knife, as the roots of marine plants otherwise give much trouble; but in dry sandy soils, further away from the sea, long-handled shovels of wood or steel are preferred, the bending of the user's back being thus avoided at the expense of power.

The total amount of earthworks, inclusive of station-yards, amounted to over 4,000,000 cubic yards.

\section{Permanent Way.}

The rails adopted for the Lutai-Tongku line were 60 lbs. per yard, Sandberg's section. The Tongku-Tientsin line was laid with $70-1 b$. rails of the same type, with a view to eventually running fast through trains to Peking should the line be extended. The sleepers were either Hinoki, or chestnut, procured from Japan; the former, being soft, were cut 1 inch thicker than the latter, which are 8 feet by 9 inches by 5 inches. The price delivered was from $2 s$. $3 d$. to $2 s .9 d$. each. The ballast was entirely of stonecutters' refuse procured from the Tongsan quarries. The cost delivered into cars was $2 s .2 d$. per fong, which is nearly 4 cubic yards, but the contractors never gave stuff of uniform quality, and a large quantity had to be broken by hand after delivery on the track. It is in these small items that the uselessness of Chinese supervision is most apparent, and it is here that much saving can be effected by a good foreman. In order to insure the sleepers being placed at proper distances, a gauge made of iron 2 inches by $\frac{1}{4}$ inch with horns riveted on to hold the sleepers was invariably employed, and the native masons soon learnt to drive spikes correctly; about $\frac{1}{3}$ mile per diem was thus laid, and partially ballasted.

\section{Foundations.}

Practically all the masonry is carried on pile-foundations capped by a bed of cement-concrete. Most of the piling was done by hand labour, as the hand-machines were more easily shifted from place to place, but where transport was easy, and heavy square piling needed in wharfs and bridge-piers, a 1-ton steam pile-driver placed on two barges was used. Japanese fir was chiefly employed under the masonry, but in other cases Oregon timber was used. The price of the former averaged 10d. per cubic foot, while the latter sawn square cost $1 s .2 d$. to $1 s .3 d$., and was purchased in baulks from 35 to 90 feet long. Captain Saunders' formula was employed throughout, and as no settlement or injury of any kind has in any case occurred, it may be considered accurate for practical

$$
\text { U } 2
$$


purposes. Ringing-engines were repeatedly introduced for light work, but the natives could never use them efficiently, or be taught to pull together, a $\frac{1}{2}$-ton monkey, with a double-geared crab, suiting them better. The cost of driving was much higher than it should have been, but, as the bottom varied considerably, only a rough average price could be secured. A 25 -foot round pile, 10 inches in diameter, cost about $2 s$. to trim and drive in average ground.

Stone cross-drains up to 4 feet by 4 feet were placed on concrete beds only, and very little cement was used in their construction. In many cases the ground ran badly, and the foundations could only be got in with difficulty; in such places the piling was completed before any excavation was made below water-level, the tops were then sawn off or a "dolly" used to drive them to correct level.

\section{Masonry.}

The whole of the bridge abutments and culverts were built of limestone, quarried at Tongsan, and delivered into cars at $4 d$. per cubic foot, in squared blocks of from 4 to 12 cubic feet each. The cost of the completed masonry varied very much with the distance and means of transport, but averaged about $11 d$. per cubic foot if set in cement mortar. The stonemasons were excellent, but required careful looking after, or the proper bedding of the blocks was neglected. For this reason, as well as on account of the high price of cement, no rubble work was attempted. The best Portland cement laid down in Tientsin cost $17 s$. per cask, and it was. usually mixed with three times as much sand. German cement cost more, and was found in no way superior to English.

Only two sizes of stone were ordered at the quarries, and purchased at a rate per chang of 10 feet 5 inches in length, the sections being 12 inches by 24 inches, and 12 inches by 18 inches; the length of each piece might be anything above 2 feet 6 inches for the former, or 3 feet for the latter. The box-drain stones were prepared entirely at the quarry in three sizes, namely, 2, 3, and 4 feet square inside, and were paid for at a given price per chang. About 30 per cent. of the stone was sent down by rail after the track was laid, and the drains were constructed after all other work had been completed, the trains meanwhile being run over on huge baulks of timber placed on mud sills set well back on the earthworks.

The native masons have only two tools, a short heavy hammer with a cup-head on one face, and flat on the otner, with a groove for a steel blade, which is occasionally used for fine dressing; 
the other tool consists of a wooden handle with an iron socket, into which chisels are fitted and used for all heavy work. For ordinary chipping the chisel is used without the handle, and is hit with the cup-face of the hammer. Quarrymen use wedges as in Europe, but strike with heavy sledge-hammers placed on a pliable shaft about $\frac{3}{4}$ inch in diameter. They can earn about $7 d$. per diem, and at this rate more modern systems of working cannot be introduced with advantage, and there is, moreover, practically no waste as with blasting operations. The men use their short crowbars with wonderful effect, and thus work huge masses of stone up steep inclines or planks, or into carts and wagons. Where rapidity is an object, the load is slung on poles, to which, again, other poles or shoulder-sticks are attached, and the whole lifted bodily by a number of coolies. By this means a load, amounting to a picul (133 lbs.) per man, can be carried by them for a considerable distance by a succession of short runs.

\section{Bridges, \&c.}

A large number of bridges and flood-openings have been constructed, amounting, on the total length of railway from Linsi to Tientsin, to sixty-five structures of one hundred and forty-six spans, from 12 feet up to 120 feet in the clear, giving 4,716 feet of opening. In addition to this there are one hundred and two drains, with a total area of 1,110 feet.

The most important bridge is at the crossing of the Pehtang River at Hanku; it consists of ten deck-spans of 50 feet, eight of 30 feet, and a swing-span of 60 feet. The abutments are of masonry, as in all the bridges, but owing to want of funds and of time, timber piers were used. 'The river-bottom was so bad that only 4 tons could be placed on a pile driven 30 feet into it, and cylinder foundations would have been too expensive. The actual cost of the bridge was under $\$ 8,000$, whereas a solid structure of three spans would have cost about $£ 26,000$. It is in such cases as this that the English engineer must give up his ideas of substantial construction, and borrow from his American brethren. The problem was to bridge over the river safely for ten or twelve years, and to place the structure so as not to interfere with the building of a first class bridge whenever the funds should admit of it. A calculation of the cost of carrying a ton weight across bridges of various designs, including up-keep and interest on capital, proves that such inferior work is not so far behind the best types in the elements of financial economy; but the danger of fire, and where 
spans are short and winters severe, of damage by ice, must alsocarry due weight. In 1887 iron girder-work was remarkably cheap, and partly for this reason, and partly because the extreme variation of climate renders trussed timber structures unsuitable, the Author decided on using iron exclusively for all superstructures, more especially as the natives are careless watchers, and fires probable during the long dry season. The girders on the Hankn bridge are therefore all of the plate type, the track being laid on deck-stringers bolted to top flanges, and spaced 12 inches in the clear. A guard-rail is checked down on to these to keep them in place.

'The piers consist of square Oregon piles driven at 30 to 36 inches centres, well braced, and capped with heavy timbers securely strapped to piles. As thick ice constantly floats up and down with the tide during the early spring, ice-dolphins have been placed at both ends of each pier. 'The ice runs up the inclined spurs, and breaks by its own weight. In the spring of 1889 , blocks of ice mounted each other several feet thick and jammed at the bridge; one pier was bent out of the vertical to a serious extent, but fortunately the tide turned before further damage was done, and the elastic timbers sprang back into their place, demonstrating effectively the good hold they had on the bottom.

About 2,000 junks pass up the river every year to trade at Lutai, and to provide for this a swing span was fitted at the deep-water end of the bridge. The free end of the bridge is levelled up by capstan-headed screws, and provided with lockinggear so placed in connection with a signal that the girders must be exactly in position before a train can be signalled to pass. When the river is closed during winter, the rails are properly fished and the locking-gear removed.

Before leaving the subject of bridges, mention may be made of the Pei Ho bridge. This structure was intended to connect the south side of 'Tientsin and the foreign settlement, with the railway terminus on the north bank of the river. The bridge was specially designed so as to cross solely on Chinese property, but after much work had been done, it was moved to a site some 1,000 feet lower down, one end being on the French Concession. The new position was a very inferior one, being near a curve in the fairway, and the central swing-span system was not well suited for the situation. While the Author was in India, a clique, headed by certain high officials, who detested the railway, determined to foster trouble with the junk people, who were glad enough to seize the chance of a dispute with some show of right on their side. So great was the clamour raised that the Viceroy finally 
gave the order for the nearly completed bridge to be destroyed, although hundreds of the largest junks liad already safely passed through on their way to the city. The railway company refused to take it away, and the opposing officials had to secure men and the necessary plant from the various arsenals. The bridge had a central pier on four iron cylinders, 7 feet in diameter, filled with concrete; on this was a swing span 150 feet over all, giving two clear openings of 60 feet, or considerably over double the beam of the largest junks ever known in North China. The approaches consisted of four spans of 25 feet on each side, and the width of roadway was 25 feet between handrails. The ironwork was made by the Patent Shaft and Axletree Company of Sheffield, from designs by Mr. James Cleminson, M. Inst. C.E., the Company's consulting engineer in London. The loss to the railway company was some $£ 8,000$; but most of the girder-work has been altered and used for bridges on the Kaiping-Linsi Extension. The stone abutments now alone remain to mark the site, monuments of intrigues and jealousy, which form the real barrier to China's advancement. No better instance could be given of the difficulties which beset the path of those who would improve this country, even under the most liberal-minded and powerful Viceroy that China has ever seen, and at whose express desire the work was undertaken.

\section{Wharves, Station Yards, \&c.}

The Company's wharfage is placed 1 mile above the strong forts which defend the mouth of the Pei Ho River, and is arranged to accommodate three steamers; lower down the same reach, the mining company have also wharfage for coaling three vessels at a time. Care has been taken to secure ample frontage and space for junks higher up the river. It is not likely, however, that this will be an important trading point until railways extend much farther than at present; but it must certainly become, one day, a very suitable place for landing goods for Peking and Mongolia. Unfortunately, only steamers drawing 12 feet can get over the bar, so that a great deal of lightering must be always carried on, unless indeed the barrier be dredged or trained further seaward. The gulf itself is extremely shallow, and is rapidly being filled up by silt from the Yellow River and other less important streams. One 25-ton derrick, and two 4-ton cranes are placed for dealing with heavy cargo; but, as a rule, the steamers rarely carry anything but light stuff, which is best managed with their own winches and numberless coolies. The whole of the 
wharves are of Oregon timber, and project some 90 feet into the stream, which is at this point 800 feet wide, with a 20 -foot fairway at low tides. There is also a smaller wharf at Tientsin, mostly used for native cargo and for the supply of coals to town and shipping.

Beyond four running sheds, the company has spent little money on buildings, the stations being brick or mud structures, which are quite good enough for the traffic obtained. An extensive station was laid out at Tientsin, but was stopped when the extension to 'Tung Chow was prevented; however, the Company wisely secured ample land at all important points.

Several cases of trains being divided and engines derailed occurred at first, but this has been entirely prevented by an apparatus which will not allow the points to be moved until a bolt in the centre of the track is first manipulated. The native does not care for the trains, and it is useless to try and teach a new man every few days; but he learns at a glance that he cannot meddle with the bolt in the track without certain loss of his own life; thus all further trouble and fly-shunting has been put a stop to at a trifling cost. Interlocking gear is used at the junction at Tongku; but the natives constantly steal the parts of the apparatus which are outside the cabins. So far, it has been found impossible to maintain distant signals unless a watchman resides near each, a species of blackmail being imposed by the villagers along the whole route. Owing to accidents having occurred by the destruction of a signal-arm, the Author determined to adopt the suggestion made many years ago in England-namely, that the absence of a signal-arm should invariably mean danger; the arm being raised for line clear. However serious such an alteration would prove in Europe, it was a very simple matter in China, and effectively removed a source of danger in a country of storms and ever-pilfering coolies.

The stations are connected by a telegraph worked with Morse instruments of Danish manufacture, the operators being students from the Tientsin Telegraph School, who also act as interpreters in the ticket-offices. No trains can be moved by telegraph, the staff system being rigidly enforced throughout.

Level-crossings are numerous-another evil inseparable from economical construction in flat countries. They are protected by gates and signal disks, so attached to them as to be visible to drivers for a considerable distance. The gatemen are, however, very unreliable, and no dependence can be placed on any signals after dark. 
Locomotives.

The Company have in all seventeen locomotives, as follows :-

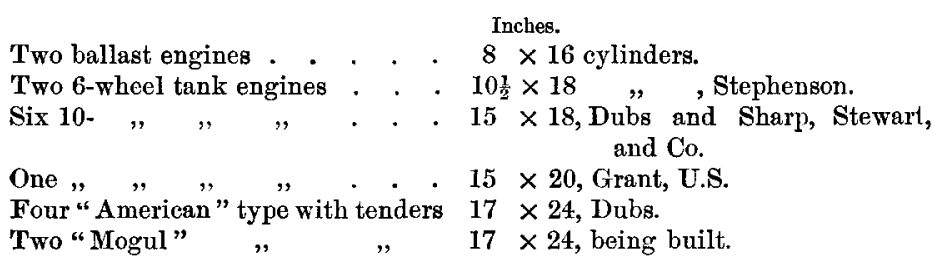

In spite of the extreme badness of the water, a considerable mileage is secured, but not without injury to the boilers; so far, steel has given results quite equal to copper for the fire-boxes; but it will require a longer trial to decide which is preferable.

The American engines were built to the same order as the six ten-wheel tank-engines, but cost considerably more. The boiler steams better than any on the line; it is of the Belpaire type, and burns more coal than the other engines doing the same worknevertheless, it is a favourite with the drivers. The driving wheels are 48-inch, while those of the other engines have 42-inch only; but a longer stroke of piston gives the same tractive power of $10,000 \mathrm{lbs}$.

These engines were only intended to run at 20 miles per hour; but it is impossible to make the drivers keep to this, and 35 has been repeatedly reached when making time. In future, no driving wheels will be under 48 inches on the tread. The whole of this class have six drivers, with a pony-truck at each end. The tank is of saddle pattern. The engines weigh from 38 to 42 tons in working order, as some have more cast-iron than others in their wheels and other parts. They are designed for use on 45-1b. rails, and are carefully equalised throughout. The larger engines are used exclusively on the heavier track of 60 to $70-1 \mathrm{~b}$. rails, and it is hoped that in future no main line will be laid with anything lighter. The passenger engines have a bogie in front, with four coupled 70-inch drivers. Tenders are placed on bogies with 36 -inch wheels; but in future, the ordinary freight-bogie with 42-inch wheels will be employed. All cylinders are placed outside, with the valve-chest on the top.

During winter there was much trouble with the pumps freezing up; but this has been overcome by introducing a steamjet into the suction-pipe, as is commonly done in the United States. Several injectors have been tried, but have not given 
perfect satisfaction in summer, when the water, especially in tank-engines, is very hot, and also in winter steam has been too freely used for heating. Water is too valuable to allow of the waste which often occurs in getting injectors to work, and donkeypumps are still preferred both by drivers and their native firemen.

The average consumption of coal is $40.18 \mathrm{lbs}$. per mile, which is not at all excessive, as the quality of the fuel is 10 per cent. inferior to Newcastle coal, and the boilers are affected by the saline nature of the water supply. The trains commonly consist of from thirty to forty vehicles, carrying some two hundred passengers and 200 to 400 tons of cargo; but far heavier loads are at times taken. At present only three native and seven English drivers are employed under Mr. G. D. Churchward, Assoc. M. Inst. C.E., Locomotive Superintendent; but it is intended to utilize the foreigners chiefly as inspectors, and introduce more Chinese drivers as fast as they may be obtainable.

\section{Traffic Departyent.}

The train service is under the orders of the traffic manager, Mr. R. W. Lemmon, who has two English head-guards and a full staff of Chinese officers. Each train has either an English driver or guard, and in some cases both; but it is intended, if possible, to employ all Chinese drivers and foreign guards, as it is found that few of the Chinese are able to enforce proper discipline without serious opposition from their fellow-countrymen, who do not object to obeying a foreigner.

Between Taku and Tientsin the passenger traffic often exceeds eight hundred per diem; but only mixed trains are run, the speed being kept below 30 miles per hour, until some advantage can be secured by increasing it, which cannot be until the extension to Peking becomes possible. The first-class rates are slightly under two Mexican cents $(=0.7 d$.) per mile, and the second-class just half this amount; a special charge is made for coupés, according to number of people carried. The average rate for carrying heavy goods and minerals is about $0 \cdot 45 d$. per ton per mile; but varies with length of haul. All cash accounts are kept entirely by Chinese methods; the statistical branch, however, is still in the hands of the foreign staff, as its value is not appreciated by the Chinese authorities, who regard it as wasted labour.

Soon after the Author had left on a visit to Europe in the spring of 1889, a serious accident occurred on the Taku-Tientsin section, by which five passengers, one English driver, and one 
native fireman lost their lives. This was caused by the driver persisting in starting before the train coming from the opposite direction had arrived. There happened to be no second Fnglish official at hand to prevent him doing so. Even after this, the Chinese were very unwilling to admit their need of "foreign" help for the safe working of the trains.

\section{Surveying.}

There was difficulty in securing fairly good surveys without attracting attention by chaining, or any detailed work. Obviously, anything within three per cent. of accuracy was sufficient, and the following method sufficed. The instruments used were a small 3-inch theodolite, surmounted by a prismatic compass, fitted so that it could be easily detached. The former is used to measure the angle subtended between two flags, say $\mathrm{BK}$ in Fig. 2 , which are placed by the leader of the party so that one is at exactly

Fig. 2.

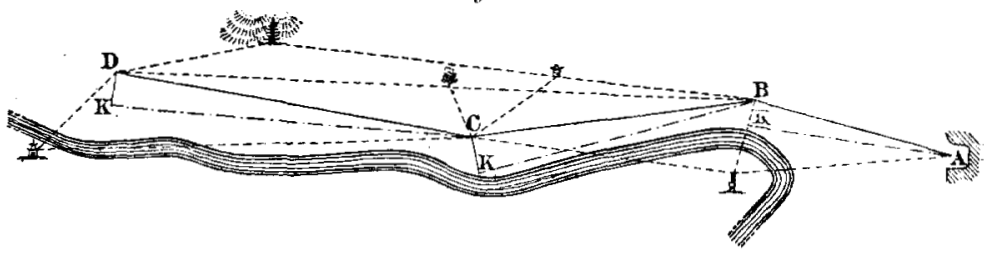

right angles to the line of sight. This base is usually 100 feet in length, so that the cosine of the angle gives the distance. The base lines $\mathrm{B} \mathrm{K}, \mathrm{C} \mathrm{K}, \mathrm{D} \mathrm{K}$, are laid out by a wire rolled on a reel which forms a part of the ranging-pole. The other flag is on a tripod, with a box-square attached to its top, into which a rod is thrust. Four men without horses can do about 15 miles a day in open country, securing all landmarks and principal villages by cross bearings, as shown in $F i g$. 2. The same system has been used for river-and canal-work, the base being a lofty mast fixed in a boat, the angle being read by a sextant. The Author and Mr. Cox, in the winter of 1888-9, surveyed from near Peking to Tientsin in four days, and thus passed so rapidly over the ground that they were scarcely noticed. The party had several horses, which were, however, rarely employed.

The correctness of this system as regards length of traverselines was found by trial to be within 1000 of accuracy; but the 
compass bearings are usually much less reliable-yet, if time permits, theodolite-readings ean be taken in preference. The great advantage of this system is that, without exciting too much attention (sometimes a dangerous affair in China), many triallines can be run at small cost, and the route repeatedly shifted for any official caprice without the disappointment incidental to such a proceeding after a costly survey of the usual kind. To survey the numerous graves, which, at a glance, an engineer knows he cannot go near, would be wasted time and energy, and it is wiser, after a careful examination of the country, to at once try to drive a centre line in the correct direction, and after plotting this, to correct it as the obstructions may require. The Chinese, as a rule, invariably desire to have the railway as far from their towns, \&c., as possible; but when the line is open, like people elsewhere, they lament that their demand was agreed to and acted upon. Unlike the Japanese, the Chinese students attached to the railway service have not as yet shown any aptitude for accurate surveying, but this is possibly due to the danger that they incur from the mobs which speedily collect, and the limited means provided for their protection in case of any disturbance.

\section{European Staff and Climate.}

One of the greatest difficulties in all introductions of western arts and manufacturing into the far East, is that of securing suitable Europeans or Americans to carry out the undertakings. Technical knowledge alone is insufficient to render a man capable of dealing efficiently with a people whose ideas are so entirely different from what he has been accustomed to previously. It is only those who combine a complete knowledge of their profession with a high sense of duty and tact, so that, while apparently giving way, they secure the desired result, who can really hope to do very much good. Not a little of the honour of introducing a better impression of foreigners to the Celestial mind is due to Mr. R. R. Burnett, M. Inst. C.E., who, however, was not spared to see the colliery at its prime, or the railway, which owes its existence to the success of the former. After much hard pioneer-work in Mongolia, Corea, and numerous parts of China, he left the Mining Company in 1882 to become the engineer and manager of a large undertaking on the Yangtze, but before work could be commenced he fell ill in Anhwei, and returned to Shanghai only to die. His agreeable manners and fine appearance, quite apart from his large and varied engineering ability, made him a great favourite with 
all who really knew him, and in a remarkable degree smoothed the way to the introduction of European skill into China.

The climate of Northern China has changed during the last twelve years, and malaria has been very prevalent since the great floods of 1887, the summers of 1888 and 1889 being extremely unhealthy, and the death-rate amongst the Chinese unusually high. The most serious complaints are those prevalent all over China, namely, typhoid fever, dysentery, and a form of cholera; only one mild case of small-pox is to be noted, although it is very common amongst the natives during the winter months, but there is considerable discomfort from the sudden changes of temperature during the spring and autumn. Though the temperature in the province of Chili ranges from below zero to $105^{\circ}$ in the shade, the cold is not so trying as that of England, owing to the extraordinary dryness of the winter months. The rains begin in July, and for two months are almost continuous, the country soon being flooded to a serious extent. It will thus be seen that engineering works can only be carried on for a short period of each year, except under serious difficulties. In 1888-89 a considerable amount of masonry was erected during the coldest weather by using 8 per cent. of sea salt mixed with the water employed for the cement mortar, and the results appear excellent, but the short hours worked by the men, and the difficulty of handling tools, except under a bright sunshine, renders all winter work out of doors unusually expensive. Luxury of any kind is practically unknown outside of the foreign settlements along the coast, and the railway man of the future must expect to be isolated from his fellows in situations where nothing but an intense love of his work and of nature can make life endurable.

In the Appendix will be found a complete list of the officers employed on the railway staff, which, owing to the loss of the Tung Chow extension, has been reduced to three engineers, a locomotive superintendent, and a traffic manager, under whom are nine foreign foremen, guards and drivers. The Mining Company employ, in addition, fourteen foreigners for various purposes in connection with their collieries, shipping, and cement works.

\section{Railway OUthook in China.}

The first train reached Tientsin in August, 1888, and in the following month the Viceroy went over the whole line with a large staff of officials, returning the next day; after spending several hours at the Tong colliery, with which he was greatly 
surprised and interested. In spite of a severe attack of facial paralysis which followed, possibly owing to exposure on the carplatform during the greater part of the journey, His Excellency lost no time in attempting to push the line on to Tung Chow en route for Peking. This scheme was shortly afterwards agreed to, and duly sanctioned by Imperial edict, but, when all was ready for a start, the sanction was withdrawn, and the whole affair stopped. The opposition was undoubtedly from those officials in Peking who profit by the tribute rice being conveyed by boat to Tung Chow, and thence by an extraordinary canal system to the capital. The suggested line had already been shifted away from the river towns, and everything was done to satisfy the grave owners and opposition boat people, but this was insufficient to appease those in high authority, who would not permit any interference with their vested rights. The Throne then referred the matter to the Viceroys of Provinces, most of whom reported in favour of the scheme, having, of course, first dutifully ascertained that the Empress, the Seventh Prince, and H. E. Li Hung Chang were strongly supporting it. Things began to look a little promising, when the Viceroy of Canton reported strongly against any railway being permitted to approach Peking from the sea coast, and afterwards, to prove he was not afraid of railways, however much he detested foreign ideas, advocated the celebrated so-called Great Western Railway from Hankow to an unimportant town 7 miles south-west of Peking, keeping as far away from the coast as the nature of the country would permit. Much to His Excellency's astonishment, the scheme was at once agreed to, and he was requested to immediately raise funds and start the work, carrying out his own policy of utilizing none but Chinese capital. This was naturally found to be impossible, and to put off the evil day the Government were induced to give instructions that all rails and rolling-stock should in addition be made in China.

There is naturally in China a desire to construct their railways out of their own materials, and if for technical reasons this idea may be erroneous, it is one which all can heartily sympathise with. It must always be remembered that in China, more than elsewhere, the Government hold their position solely by the good will of the people, and the numerous powerful guilds, should their interests be in any way assailed, are quite able and willing to defend their rights. Whatever good railways can effect in the immediate future, they must, in one form or another, for a certain period, seriously interfere with a vast number of workers, who cannot be assured that the change will bring any adequate improvement to 
those who live from hand to mouth, and cannot wait for results. And such form the bulk of the Chinese population, and they can at any moment be roused by interested persons to block the path of progress. For this reason changes must be gradual, and the hardships brought about must be confined to small sections where they can be effectively remedied, and where any outery will be too small to attract serious attention. The improvement of trade and introduction of various manufactures along the line of railway will soon create new demands for labour, and the slow extension of the various branches can be then undertaken without any fear of local opposition. Under such conditions railways cannot be so economically made as in Europe; but if laid out with due care and the isolated portions eventually connected, the results would in the end be perfectly satisfactory. Unfortunately this is difficult to accomplish in a country where each province has a separate Viceroy, and every Viceroy different ideas as to what is necessary.

In many districts, and especially near large towns, the graves will form an insurmountable barrier, and in Tientsin the station yard was placed in a swamp, which required raising several feet, in order to secure a suitable site. Many graves, probably over three thousand, have been removed without very serious trouble, but these have been exclusively those of the poorer classes, who are less superstitious than their superiors, and possibly more easily influenced by money. In many places the line was deflected several hundred yards to avoid graves of parents of officials, and it is entirely out of the question to bring it anywhere near these. It is for this reason that, in spite of the excellent configuration of the land, sharp curves will be numerons in places where the population is massed. In the extreme southern provinces the dead are buried amongst the hills, and the plains are entirely free from this class of obstruction; but, on the other hand, the land is very expensive (usually over $£ 80$ per acre for rice land), and the innumerable creeks necessitate a great amount of bridging. Added to this, the more determined and warlike character of the people, and their intense hatred of foreign introductions, renders the prospects of railways in Southern China far more gloomy than in the North.

At present China possesses rather under 100 miles of standard gauge main line, and some 20 miles of 3 -foot 6 -inch gauge on the Island of Formosa. The capital so far expended on the former amounts to $1,200,000$ Taels, equal to $£ 280,000$ exclusive of wharfs and real estate not used for railway purposes, or almost exactly 
304 KINDER ON RAILWAYS AND COLLIERIES OF N. CHINA. [Selected $£ 2,800$ per mile of main line. This extremely low figure was due in a great measure to the skilful management of the Company's affairs by their agent in London, Mr. James Whittall, who took full advantage of the low prices ruling during 1888, and whose arrangements for shipping enabled the goods to be landed under peculiarly advantageous conditions.

The Paper is accompanied by various drawings, from which the Figs. in the text have been prepared. 
Papers.] KINDER ON RAILWAYS AND COLLIERIES OF N. CHINA. 305

\begin{abstract}
APPENDIX.
Engineertag Staff employed in the construction of the Rathway From Lutai to Tientstn, and from Tongsan to Linst.

A. W. H. Bellingham, Assoc.M.Inst.C.E. ${ }^{1}$. Regident Engineer, Tientsin. W. Watson, B.E., Dublin ${ }^{1}$. . . . . " " $\quad$, Tongku. Alex. Cox ${ }^{1}$. . . . . . . . . . Assistant Engineer.

T. W. T. TuckeY, B.E., Cork ${ }^{1}$ • . . . " , " "

D. P. Ricketts, Assoc.M.Inst.C.E. . . - " " ,

A. J. АRCH, Assoc.M.Inst.C.E. . . . . " " ,

A. S. VowelL ${ }^{2}$. . . . . . . . . " " " "
\end{abstract}

1 These received a gold medal from H.E. Li Hung Chang in commemoration of the opening of the railway to Tientsin.

2 These left the service prior to the completion of the railway.

[THE INST. C.E. VOL. CIII.] 


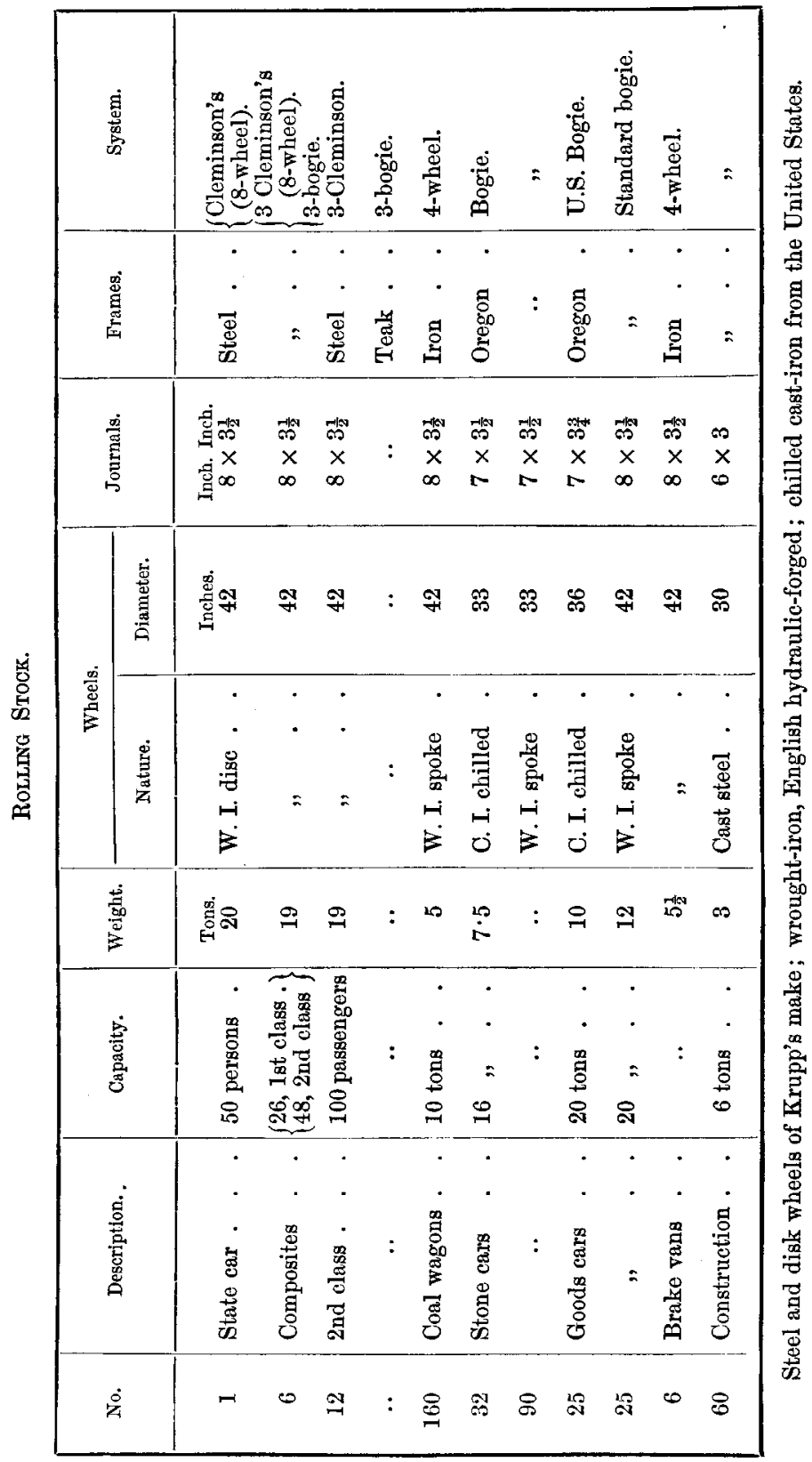

